\title{
Potential of Local Wisdom in The Development of Agricultural Law in Central Sumba
}

\author{
DyahHapsari Prananingrum ${ }^{1}$, Ari Siswanto ${ }^{2}$ \\ \{dyah.prananingrum@gmail.com ${ }^{1}$, ar-s-10@ feb.unair.ac.id ${ }^{2}$ \} \\ ${ }^{1,2}$ Satya Wacana Christian University, Jl. Diponegoro No.52-60, Sidorejo, Kota Salatiga, Jawa Tengah
} 50711, Indonesia

\begin{abstract}
The community of Central Sumba, Nusa Tenggara Timur (NTT) Province, has attempted an exploration on their local wisdom which is later formulated into a moral and cultural movement known as Back to Farm Movement that aims to develop the agricultural sector. This movement is moral since it embodies the traditional values that function as a guideline for what is believed for generations as the virtues. Additionally, this movement also serves as a cultural attribute considering that its declaration took place in a cultural event. The Back to Farm Movement is significantly crucial. As found in most other areas in the NTT Province, food availability is one of the most fundamental issues in Central Sumba. Hence, the Back to Farm Movement is expected to inspire change in the behavior of the local community so that they could be more appreciative of the lands they already have by working on these lands and taking more significant advantage of the potential economic values they have. Notwithstanding its nature as a mere moral movement, the Back to Farm Movement contains a prescriptive behavior guideline which is deeply rooted in the traditional values the community holds. Hence, from the Savignian perspective, the Back to Farm Movement is considered to be the law born of the realm of the people spirit/volksgeist. The data of this research were collected using documentary study.

Keywords: Local Wisdom, Agricultural Law, Central Sumba
\end{abstract}

\section{Introduction}

Currently, agriculture is one of the developing issues which has not yet received proper attention in terms of the policy as well as regulations. Development that could promote the growth of this agricultural sector needs to receive constant support. The adage that says economic growth will promote an agricultural industry that would, in turn, meet food demand is hardly proven since in the end it only creates food scarcity due to intense land-use conversion of agricultural to industrial purposes[1].

Responding to such a challenge, many believe that it is going to need a change in the agricultural system from traditional agriculture to the modern one. However, this notion tends to remain as a discourse with no further concrete actions, particularly from the government's side. What is the strikingly new situation is that some social communities have already possessed the local knowledge and local wisdom that embodies values that may promote the development of the agricultural sector at the community level. As Durkheim once said, local socio-cultural values are of importance and that the community in its boundless form, which encompasses individuals in time and space, hold the final position that could influence the actions toward and thoughts about these local socio-cultural values [2].

Central Sumba Regency is one of the regencies in the Province of Nusa Tenggara Timur, 
whose community has attempted an exploration of their local wisdom and performed dynamic formulation of such wisdom into a moral and cultural movement known as the "Three Movements" program which includes the "Back to Farm Movement" as an effort to address agricultural problems. The goal of "Back to Farm Movement" is to rejuvenate traditional values in attempts to improve the well-being of the community through agricultural/farming sector. This phenomenon is, in fact, impressive since it shows how local wisdom are explored to address the social problem promptly without relying too much on the government's initiatives.

Based on the previous description, the research issues that will be addressed in this paper are as follows:

a) What potential do the local wisdom the Central Sumba communities hold in developing a normative framework for agricultural management?

b) How does the institutionalization of the local wisdom take place to promote agricultural management?

\section{Literature Review}

Indonesia is a multicultural state in which the nation consists of people from diverse ethnic, racial, and religious backgrounds. Due to such diverse cultures, this affects the condition of law enforcement on the land, creates a plural form of laws throughout the country [3]. Government has always used the law to organize and legitimize social, cultural, and political organizations in order to influence changes within the society. However, such law is supposed to be adjustable and negotiable with the pre-existing social and cultural reality of society in which the underlying values and norms have already been regulating the social behaviors. Thus, there is no way to enforce the law as it is initially intended by the lawmakers [4].

Indonesia has a unique system of law. Although the law is universally enforced and applied, the practice of enforcement of which tends to be plural due to the diverse social and cultural systems that indigenous to the people. Therefore, there is a possibility of having more than one legal order of which the regulations are not the sole source of law, thus resulting in "unofficial law". [3]However, the existence of "unofficial law" should not be construed as an obstruction to the written law's legitimacy, but instead, it could reinforce that of the rule of law[5]. The pre-existing cultures and norms already contribute to the presuppositions of social order in a way that is universally accepted by the members of society. Thus, such unofficial law has become the local wisdom. [6] This is shown that local wisdom and the written law in Indonesia could work in harmony. Several research has argued that local wisdom is essential in setting the normative benchmark and framework to the legislations in its formulation, promulgation, and even implementation which are construed as a phenomenon of the law's adjustments, compromises, and adoptions to the pre-existing culture and wisdom. [7]

\section{Methodology}

This research used a socio-legal research method as the umbrella term of the method. Socio-legal research method combines legal analysis and social inquiry to seek the empirical impact or influence on the development of the recurring law[4]. The legal analysis will be based on secondary data in which texts and literature are the primary sources.[5] Whereas the social inquiry will use qualitative research method in which the analysis is derived from non- 
numerical empirical data that are taken. In specific, this article takes a case study approach, an approach which focused its scope on the specific area and phenomenon that happened within.[6] This approach will be used in order to construe the related impacts or influences of the local wisdom of Central Sumba to the development of agricultural law in the land.

As the qualitative approach is based on primary (empirical data), the will be based on an interview with key informants (including local government officials and traditional leaders) and documentary study are the main methods used in collecting data.[7] It is acknowledged that in such research the validity of data is crucial, so techniques to confirm data validity were intensely applied, mostly triangulation (in terms of both source and method) and source-based cross-checking.[8] After the data collection is completed, the final analysis promptly follows. This research uses an interactive data analysis which consists of three analysis components: data reduction, data display, and conclusion drawing followed by verification. [9] These three components regularly interact with the data collection activity during the data collection process and remain so after the data collection process is completed. Whenever data is deemed to be insufficient to support the existing conclusion, verification by using a more focused data collection is applied.

\section{Findings}

Geographically, Central Sumba Regency that is situated in Nusa Tenggara Timur (NTT) Province has a total land area that stretches over 186,918 hectares. Administratively, Central Sumba Regency is divided into five districts with a total of 66 villages.

Central Sumba Regency is categorized as a semi-arid area with a dry climate and only four months of the wet period in a whole year. Hills dominate the region's topography with varying levels of elevation. Based on the existing land use in Central Sumba Regency, the land used for agriculture (rice field, dry field, farm, pastures) is by far the largest compared to land used for other purposes such as settlement, buildings, and others.

Land used for food crop farming in Central Sumba takes up a total of $\pm 200,000$ hectares. Dryland farming system dominates the land use (by $96 \%$ of the total agricultural land), $48 \%$ is state forest and community forest, $17 \%$ is pastures, $9 \%$ is used for yard/dry field/farm, $9 \%$ is for plantation and other dryland farmings, and $13 \%$ is derelict dry land (BPS, 2008). As much as $4 \%$ of the agricultural land is used as a rice field.

The regional government of Central Sumba embodies their agricultural development policy through Regional Mid-Term Development Plan (RPJMD). It is defined explicitly that the goal/objectives of agricultural development in Central Sumba are to sustainably manage and utilize all the existing agricultural resources to provide necessities of the community, create opportunities for improving production and community productivity, and promote the progress of the local economy.

\subsubsection{Local Wisdom Potentials in Developing a Normative Framework for Agricultural Management}

Based on the field data, it is evident that Central Sumba Regency owns potential resources in the form of land, which could become the source of the community's wealth. Regrettably, such land abundance is not met by strong work ethics of the locals to manage the lands. This is reflected in the local's approach to land work: as long as their rice and corn harvest is enough for next year-round, it is not necessary to take the trouble of working for some more. It is, in fact, would reward the locals with crops - of which they could trade for 
more income to meet their daily family necessities, or sell, or even invest the profit they receive in the form of saving on anticipating long-term needs, such as education and health expenses - had they managed these potential lands properly. Unfortunately, it is indisputable that for some time, the Nusa Tenggara Timur Province including Central Sumba Regency had been given label as an area prone to famine and poverty.

From the information acquired during the field assessment, it may be concluded that in general sense, there is shared understanding regarding the Back to Farm Movement. It is primarily understood as an effort made to utilize the available natural resources as leverage to fulfill the need of the Central Sumba community, and, at the same time, improve their food security. Some respondents also asserted that the Back to Farm Movement was developed after some contemplation and consideration about the functional significance of soil and farm as a source of living and thus a genuine inspiration that came from their soul or volksgeist.[10] Their statements established the notion that the Back to Farm Movement is not an artificial movement that was generated in a brief moment. Instead, it was the result of a very thoughtful contemplation about the cultural values that reflect the ways of life of Central Sumba people who traditionally perceived the soil and farm as their source of livelihood, as shown in the saying "haka tana Manami rate" (hoeing the soil, pulling up the weed) and "tongue pini Manu, tongue auhu wawl" (feeding the chicken, feeding the hogs) which describes well the original work ethics of Central Sumba people[11].

On the other side of the spectrum, the Back to Farm Movement is also perceived as an effort to increase the diversity of the local food consumption, which therefore lessens their dependency on rice. Food diversification is a substantial element within the concept of food security of which primary goal is to break the community free from over-dependence on one single food source.

Generally, respondents view the Back to Farm Movement is in line with the people's desire and having definite goal/objective since it assigns the community at large as the beneficiary of the movement. When carried out at the most significant effort possible, the Back to Farm Movement is believed to have the ability to empower the community in their struggle to overcome their well-being problems in creative ways.

Although the main focus of the Back to Farm Movement is concerned with the issues of the fulfillment of necessities, there are, however, other important aspects to consider. Firstly, the Back to Farm Movement is expected to bring along the further impact of reducing the level of unemployment. Secondly, there is also an expectation that the Back to Farm Movement will bring about productive economic activities which will help the locals to earn more and to cover other essential needs, particularly education. Thirdly, the fundamental nature of the movement to utilize the lands owned by the Central Sumba community could also be perceived as an endeavor to preserve the ownership of the lands and therefore protect them from the risk being delivered to outsiders in the future. Lastly, it arises a perspective that sees the Movement as having the social capital dimension in terms of its capacity to revitalize social cohesion, which is reflected in the community's gotong royong (cooperation) tradition when working on the lands, a tradition which unfortunately has now started to vanish. The collective farm/dry land farming culture, which has cultural roots amongst the people of Central Sumba is believed to have been slowly wiped out. Therefore, the Back to Farm Movement is also perceived as not only a measure to tackle the community's factual problems - the problem-solving measure - but also an effort to revitalize the endangered traditional values. 


\subsection{The institutionalization of local wisdom in developing agricultural management}

It is in response to such condition that the Central Sumba community proclaimed their moral and cultural commitment they manifested in the Three Movements program, one of which is called the Back to Farm Movement. The Back to Farm Movement aims to promote the use of the existing potentials that the community could find in their land resources. They may use it to resolve their food scarcity issue by using such potentials to meet the requirement of their protein and nutrition intakes. At the same time, it may also serve as a source of income for the locals by trading agricultural produce. The characteristic of the Back to Farm Movement is unique by two reasons. First, instead of being packaged as an 'instruction' from the regional government to the community, it was being introduced as a commitment coming from the consciousness of the community themselves. In other words, the movement applies the bottom-up approach, instead of the rigid bureaucratic imperative approach. Second, it also enables the rules to adjust quickly to the required situation and condition to create a fair result.[12]

The centrality of land in the life of Central Sumba community has occurred for an extended period. The ancestors of the people of Central Sumba believed that land was their source of well-being, and an integral part of the life cycle: the human is born from the soil, lives from the soil, and eventually dies returning to the soil. Therefore, it is a flawed premise to say that the Back to Farm Movement is introducing new values to the community; instead, it is appropriate to say that the movement is rejuvenating the old traditional values which have been significantly endangered by modernization. Therefore, the re-discovery of the old traditional values, the genuine volksgeist, where the land is highly appreciated is not only a realistic endeavor but also relevant.

\section{Conclusion}

Concerning the potential of Central Sumba community's local wisdom in the development of the normative framework for agricultural management:

Traditionally, the Central Sumba community owns the perspective that perceives the land as their source of life and has developed agricultural paradigm focussed on togetherness, communalism, and nature protection. The community's high regard for the significance of soil is consistent with their cultural perspective on land management, which is necessarily implying their appreciation to soil and plant as much as their appreciation to human beings. Hence, essentially, there is a robust sociological reason to say that there are local wisdom potentials that can be rejuvenated to assist the process of developing a system for food cultivation which integrate the cultural aspects of the community. Thus, in such a situation, agricultural law reform in Central Sumba could be done better since it codifies custom[13].

Concerning the institutionalization of local wisdom, both formally and informally, to promote agricultural management. The existence of local wisdom in Central Sumba community concerning the land as natural resource potential has encouraged several community components to institutionalize their local wisdom in the land management sector as reflected by the Back to Farm Movement. Informally, the institutionalization of local wisdom is carried out through the Back to Farm Movement, which is expected to promote community well-being by combining local wisdom values, natural resources potentials, and to some degree, bureaucracy. 


\section{References}

[1] E. Tsioumani, "Beyond access and benefit-sharing: Lessons from the law and governance of agricultural biodiversity," J. World Intellect. Prop., 2018.

[2] P. Beilharz and B. Zygmunt, Masters of Social Thought. London: Sage Publications, 2002.

[3] F. von Benda-Beckmann, "Legal Pluralism and Social Justice in Economic and Political Development," IDS Bull., 2001.

[4] F. von Benda-Beckmann, "The Multiple Edges of Law: Dealing with Legal Pluralism in Development Practice," World Bank Leg. Rev., no. 2, pp. 51-87, 2006.

[5] R. Janse, “A Turn to Legal Pluralism in Rule of Law Promotion?," Erasmus Law Rev., 2014.

[6] A. Harding, "Global Doctrine and Local Knowledge: Law in South East Asia," Int. Comp. Law Q., 2002.

[7] R. F. Young, "Modernity, postmodernity, and ecological wisdom: Toward a new framework for landscape and urban planning," Landsc. Urban Plan., 2016.

[8] R. Banakar and M. Travers, "Theory and method in socio-legal research," Oñati international series in law and society. 2005.

[9] A. A. Razak, "Understanding Legal Research,” Integr. Dissem., 2009.

[10] J. W. Creswell, Qualitative inquiry and research design: Choosing among five traditions. 1998.

[11] Dobinson Ian and Johns Francis, "Qualitative Legal Research," in Research Methods for Law, 2007.

[12] N. Golafshani, "Understanding reliability and validity in qualitative research," Qual. Rep., 2003.

[13] S. Vago, Law and Society. Boston: Prentice Hall, 2013. 